\title{
POLIIIICA DE COTAS RACIAIS, OS "OLHOS DA SOCIEDADE" E OS USOS DA ANTROPOLOGIA: O CASO DO VESTIBULAR DA UNIVERSIDADE DE BRASSLLLA (UNB)*
}

\author{
Marcos Chor Maio \\ Fundação Oswaldo Cruz - Brasil \\ Ricardo Ventura Santos \\ Fundação Oswaldo Cruz e Museu Nacional/Universidade Federal do \\ Rio de Janeiro - Brasil
}

Resumo: A Universidade de Brasília (UnB) foi a primeira instituição de ensino superior federal a adotar um sistema de cotas raciais para ingresso através do vestibular, a partir do segundo semestre de 2004. A iniciativa da instituição, devido sobretudo à estratégia de estabelecer uma comissão para homologar a identidade racial dos candidatos a partir da análise de fotografias, gerou um intenso debate na sociedade, que se estendeu para muito além da comunidade universitária. Sugerimos que ao lidar com uma questão sociopolítica, ou seja, procurar estabelecer um privilégio para determinado grupo com o intuito de corrigir injustiças históricas e, ao mesmo tempo, controlar os potenciais "burladores raciais", o aparato acadêmico-burocrático da UnB, em aliança com o movimento negro, buscou mobilizar parâmetros supostamente objetivos. Esses critérios, afeitos a uma sorte de anátomo-psicologia racial, geraram uma temporada de disputas científico-políticas de amplo espectro, na medida em que os próprios critérios estabelecidos foram objeto de controvérsias. Um aspecto particularmente significativo é que no caso UnB há o acionamento de temas caros

\footnotetext{
* A primeira versão deste artigo foi apresentada no seminário temático "Formação de Estado e Construção da Nação: Perspectivas Sociogenéticas e Antropológicas na Análise de Processos Sociais no Brasil Contemporâneo", realizado durante o XXVIII Encontro da Associação Brasileira de Pós-Graduação em Ciências Sociais, Anpocs, Caxambu, Minas Gerais, de 26 a 30 de outubro de 2004, coordenado por Antônio Carlos Souza Lima, Piero de Camargo Leirner e Gilberto Hochman. Agradecemos o auxílio de Claúdia Garcia e também os comentários de Adriana Vianna e Carlos Valle, os dois debatedores da sessão na Anpocs. Carlos Coimbra Jr., Heloisa Pontes, Jane Beltrão, Luiz Otávio Ferreira, Maria Cátira Bortolini, Mario Grynszpan e Mariza Peirano leram uma versão preliminar do trabalho, tendo contribuído com valiosas sugestões.
} 
à reflexão antropológica, ou seja, no plano das técnicas, chegou a envolver a prática da antropologia enquanto atividade de "peritagem racial". Nosso intuito nesse trabalho é refletir sobre esse contexto, particular em suas especificidades, mas de considerável abrangência no que tange ao envolvimento (e aos usos) da antropologia na dinâmica de processos contemporâneos.

Palavras-chave: antropologia, Brasil, cotas raciais, educação superior.

Abstract: The University of Brasilia (UnB) was the first Brazilian federal university to adopt racial quotas as part of its admission procedures, reserving $20 \%$ of places in all courses for "black" students. The system came into effect in the second semester of 2004. The university's initiative generated intense debate not only in the academic community but throughout Brazilian society, in particular because the means adopted to decide eligibility under the program was to set up a commission that determined the racial identity of candidates by analyzing their photographs. The university bureaucracy, allied with the black movement, chose this method to deal with a sensitive socio-political issue. The aim was to privilege black Brazilians in order to remedy historical injustices, and at the same time eliminate potential "racial cheaters," by setting supposedly objective parameters. The application of these criteria, influenced by a kind of racial-anatomical psychology, led to a period of wide spread scientific and political dispute, especially because the criteria themselves were highly controversial. A particularly significant aspect of the University of Brasilia case is that it requires us to think about the uses and abuses of anthropology, since on a technical level the practice of anthropology was invoked as "racial expertise." Our purpose in this paper is to reflect on the context of this case, which, although specific, points to the wider involvement (and to the uses) of anthropology in the dynamics of contemporary political and social processes.

Keywords: Anthropology, Brazil, higher education, racial quota system.

Os pormenores do trabalho da comissão não chegaram a ser divulgados. Soube-se que era composta de cinco integrantes e que a tarefa era analisar mais de 4 mil fotografias. Não havia muito tempo, pois o trabalho precisava ser concluído em poucas semanas. Os nomes dos componentes foram mantidos em sigilo. Havia dentre eles um antropólogo. 
As especificações a serem seguidas não eram muito claras, mas os indivíduos fotografados deveriam ser confirmados ou não como "negros" a partir de características físicas como cor da pele, textura do cabelo e formato do nariz. As fotos mostravam os indivíduos na mesma posição, segurando um número de identificação.

Para aqueles familiarizados com a história da antropologia e da medicina, a descrição acima pode fazer lembrar práticas pretéritas, comuns entre o final do século XIX e o início do século XX. Contudo, se adicionarmos alguns detalhes, a distância entre o passado e o presente esmaece. As imagens que a comissão recebeu para analisar foram obtidas através de uma câmera digital e gravadas em um CD. Essa hibridação entre conceitualizações e tipologias raciais de um passado distante com a modernidade da era digital aconteceu em maio-junho de 2004 na Universidade de Brasília, como parte do processo seletivo do primeiro vestibular de cotas raciais da instituição. Coube à comissão, designada pelas instâncias superiores da UnB e da qual participavam inclusive professores universitários, determinar quem eram os elegíveis, ou seja, os "negros” que poderiam concorrer às vagas alocadas no sistema de cotas raciais.

O Brasil é um país neófito em políticas públicas no campo das ações afirmativas de recorte racial. Não obstante, tem sido freqüente a implantação de sistemas de cotas que, como observou Htun (2004, p. 60), constituem estratégias extremas de ação afirmativa. ${ }^{1}$ Não surpreendentemente, os eventos da UnB geraram acalorados debates no âmbito da sociedade civil, com posicionamentos desde apoios explícitos, oriundos do movimento negro e de setores da academia (Carneiro, 2004a, 2004b; Carvalho, 2004; Diniz; Medeiros, 2004; Féres Júnior, 2004; Segato, 2004) $)^{2}$ até críticas veementes. Nesse caso, o vestibular da UnB chegou a ser rotulado de "tribunal das raças" (Folha de São Paulo, 2004). Foram feitas ainda alusões aos paralelos entre o que estava acontecendo em

\footnotetext{
${ }^{1}$ Segundo Grin (2004b, p. 107), a política de ação afirmativa é “um expediente políticoadministrativo do governo federal que busca, por meio de intervenções no mercado, ou de incentivos nos setores públicos e privados, diminuir os efeitos da discriminação nas oportunidades de mercado e em educação para a população negra, entre outras minorias. Para tanto, uma redistribuição de oportunidades contemplaria minorias vitimadas por longa história de discriminação.”

${ }^{2}$ Há ainda textos de réplica de dirigentes da UnB, gerados a partir das críticas que a iniciativa da instituição sucitaram (ver, por exemplo, Mulholland, 2004a, 2004b; Rabelo, 2004).
} 
Brasília com práticas tipológicas de identificação racial que foram comuns no passado no âmbito da antropologia física e da medicina legal, e que são vistas de forma crítica pelas ciências sociais contemporâneas (Fry, 2004; Góes, 2004; Grin, 2004a; Pires, 2004; Ribeiro, 2004; Santos, 2004a, 2004b; Santos; Maio, 2004a, 2004b, 2004c). Um ministro do Supremo Tribunal Federal criticou a decisão da UnB declarando que "se alguém se declara negro é porque negro é... Vamos parar de imaginar que todos são salafrários”. E concluiu: “Fotografia não comprova nada” (Weber; Gallucci, 2004). Em posicionamento público, a Associação Brasileira de Antropologia (ABA) manifestou sua apreensão quanto ao que denominou de "autoritarismo vigente" no processo de adoção das cotas pela UnB (CrerABA, 2004). ${ }^{3}$

Ao lidar com uma questão sociopolítica, ou seja, procurar estabelecer um privilégio para determinado grupo com o intuito de corrigir injustiças históricas e, ao mesmo tempo, controlar os potenciais "burladores raciais", o aparato acadêmico-burocrático da UnB, em aliança com o movimento negro, buscou mobilizar parâmetros supostamente objetivos. Esses critérios, afeitos a uma sorte de anátomo-psicologia racial, geraram uma temporada de disputas científico-políticas de amplo espectro, na medida em que os próprios critérios estabelecidos foram objeto de controvérsias.

O caso UnB reúne um conjunto expressivo de elementos relacionados aos rumos das políticas públicas, das propostas de transformação social e do papel do Estado no Brasil contemporâneo. É um microcosmo de processos sociopolíticos bem mais disseminados em curso no país. Um aspecto particularmente significativo é que há o acionamento de temas caros à reflexão antropológica, ou seja, no plano das técnicas, chegou a envolver a prática da antropologia enquanto atividade de "peritagem racial”. Nosso intuito neste trabalho é refletir sobre esse contexto, particular em suas especificidades, mas de considerável abrangência no que tange ao envolvimento (e aos usos) da antropologia na dinâmica de processos contemporâneos.

\footnotetext{
3 Há na Internet a página “Acompanhando as Ações Afirmativas no Ensino Superior” (disponível em: <http://www.observa.ifcs.ufrj.br>), que vem compilando materiais relativos às cotas no Brasil, incluindo materiais relativos ao caso UnB.
} 


\section{Os rumos das políticas de acão afirmativa no Brasil}

A experiência da UnB se insere no contexto mais amplo da discussão e implementação de políticas de ação afirmativa que, no caso brasileiro, vêm adquirindo maior visibilidade na versão "cotas raciais" para ingresso no ensino superior. Esse processo revela um momento de inflexão do poder público desde um discurso centrado no elogio à miscigenação e à ausência de conflito racial para o do reconhecimento não apenas do racismo como um grave problema de iniqüidade social, mas também da necessidade de se criar instrumentos políticos que o debele a partir do diagnóstico das desigualdades raciais. Ou seja, de um Estado "neutro" em matéria racial até meados dos anos 1990, observa-se a formulação de propostas de políticas públicas racializadas. Como ocorreu tal mudança? Para responder a essa questão é necessário abordar, de forma sucinta, a atuação dos diversos agentes e agências (movimentos sociais, academia, iniciativas estatais, instituições intergovernamentais, fundações filantrópicas internacionais, fóruns multilateriais) envolvidos nesse processo.

A redemocratização da sociedade brasileira inaugurada no final dos anos 1970 coincide, no plano das ciências sociais, com a divulgação de novas interpretações sobre as relações raciais no Brasil. Até então, os estudos patrocinados pela Unesco no início da década de 1950 e seus desdobramentos nos anos 1960 haviam revelado as tensões entre o mito da democracia racial e o "racismo à brasileira". O inventário realizado pelo chamado Projeto Unesco sobre o preconceito e a discriminação racial caminhou pari passu com a reiteração da diferença com relação à experiência norte-americana. O ciclo de pesquisas da Unesco tornou-se um marco, entre os cientistas sociais, na caracterização da questão racial no Brasil (Maio, 2001).

A partir do final da década de 1970, pesquisadores como Carlos Hasenbalg e Nelson do Valle e Silva, com base em dados quantitativos e apoiados em uma visão crítica da teoria da modernização e de determinadas análises estruturalistas, contestaram interpretações oriundas do Projeto Unesco, a exemplo de Florestan Fernandes, quanto à natureza pré-moderna do "racismo à brasileira" e à subsunção da categoria raça à classe. Uma das críticas ao sociólogo paulista deve-se à interpretação do preconceito racial como um resquício da herança escravocrata e, como tal, tendente a desaparecer com o surgimento de uma sociedade capitalista, democrática, 
aberta e competitiva. Hasenbalg (1979) se contrapôs a Fernandes afirmando que preconceito e discriminação sofreram alterações após a abolição da escravidão, assumindo novas funções e significados no contexto da estrutura social capitalista. Ao mesmo tempo, ele pondera que manifestações racistas do grupo racial dominante não são sobrevivências do passado, mas estão relacionadas com benefícios simbólicos adquiridos pelos brancos no processo de competição e desqualificação dos negros. Assim, Hasenbalg sustenta que não há uma lógica inerente ao desenvolvimento capitalista que gera incompatibilidade entre racismo e industrialização.

Simultaneamente, o movimento negro contemporâneo, uma constelação de associações religiosas, culturais, políticas, filantrópicas com graus de articulação muito variados entre si, ao longo dos anos 1970, quer sob a influência político-cultural norte-americana, especialmente do movimento dos direitos civis, quer sob a ascendência dos intelectuais marxistas africanos das lutas anticoloniais de libertação nacional contra o império português (Amílcar Cabral, Agostinho Neto, Samora Machel), criticaram a visão integracionista das lideranças negras brasileiras entre os anos 1930 e 1960. A virada político-ideológica é comumente atribuída à criação do Movimento Negro Unificado Contra a Discriminação Racial, em 1978. Nesse período, no entanto, o raio de ação do associativismo negro era bastante limitado (Gonzalez, 1982, p. 30-66; Santos, 1988).

Ao longo da década de 1980 diversos esforços foram envidados na construção de uma aliança entre sociólogos das relações raciais e movimentos sociais na luta contra o racismo a partir de fóruns de debates, projetos de pesquisa e publicações. O exemplo do Centro de Estudos AfroAsiáticos é bastante representativo (Segura-Ramirez, 2000). Ao mesmo tempo, iniciativas estaduais (como a criação de conselhos e secretarias voltadas para a população negra), eventos históricos (como o centenário da Abolição), a Constituição de 1988 (com a Lei Caó) e a criação pelo Ministério da Cultura da Fundação Cultural Palmares deram maior proeminência à luta anti-racista. Concomitantemente, há um avanço no processo de institucionalização dos estudos raciais, com a criação de centros e núcleos voltados para pesquisas no âmbito da demografia, da educação, do mercado de trabalho, do nível de renda, dos casamentos inter-raciais, etc. (Fry, 2000; Hasenbalg, 1996).

Até meados dos anos 1990, a adoção de políticas de ação afirmativa no Brasil era objetivo de controvérsias tanto no movimento negro (Contins; 
Sant'ana, 1996; Maio, 1993) como entre cientistas sociais do campo das relações raciais (Souza, 1997). Todavia, o tema entra na agenda política do governo Fernando Henrique Cardoso ao instituir, por decreto, no dia 20 de novembro de 1995, o Grupo de Trabalho Interministerial para a Valorização da População Negra, por ocasião de uma manifestação em homenagem aos 300 anos de Zumbi dos Palmares. Essa iniciativa veio no bojo do Programa Nacional de Direitos Humanos (PNDH), do governo federal (Telles, 2003).

Em junho de 1996, no Palácio do Planalto, o Ministério da Justiça, com o apoio do Itamaraty, promoveu o seminário internacional Multiculturalismo e Racismo: o Papel da "Ação Afirmativa” nos Estados Democráticos Contemporâneos, com a presença de renomados acadêmicos brasileiros e brasilianistas norte-americanos, com o intuito de colher subsídios para a formulação de políticas voltadas para a população negra (Souza, 1997). A reunião foi chancelada por um governo que reconhecia oficialmente a existência do racismo no Brasil. O presidente Fernando Henrique Cardoso, sociólogo que fez parte, junto com Otavio Ianni, da segunda geração do Projeto Unesco, havia auxiliado Florestan Fernandes e Roger Bastide na pesquisa sobre as relações entre brancos e negros na cidade de São Paulo nos anos 1950. No início da década de 1960, Cardoso concluiu sua tese de doutorado, sob a orientação de Florestan, sobre as relações entre capitalismo e escravidão no Rio Grande do Sul (Cardoso, 1962).

$\mathrm{Na}$ abertura dos trabalhos do seminário de Brasília, Cardoso revelou certa ambivalência ao tratar dos temas das relações raciais e das ações afirmativas. Convocando os participantes a exercerem a imaginação social diante do dilema racial brasileiro e alertando para o perigo do mimetismo, clara referência ao modelo norte-americano, ele condenou a hipocrisia em face da intolerância racial no Brasil, mas, ao mesmo tempo, valorizou a ambigüidade que faria parte da formação cultural brasileira. Para um colóquio que tinha por objetivo colher subsídios para a implementação de políticas a curto prazo, tem-se a impressão que o discurso de Cardoso contempla um certo paradoxo. Isso porque, como observa Grin (2001, p. 180), “[se] inverte[m] os propósitos do encontro, no qual o reconhecimento de um problema e as considerações de possíveis padrões normativos e soluções de inspiração exógena se convertem em identificação da ambigüidade 'racial' e a criatividade para solucionar desigualdades sem necessariamente eliminar a ambigüidade”. 
De certo modo, a ambivalência de Fernando Henrique Cardoso exposta em seu discurso sobre as políticas de ação afirmativa permeará grande parte da atuação do seu governo. Não obstante uma série de propostas tenha sido introduzida no PNDH, elaborado em 1996, quanto à valorização da população negra, inclusive com a adoção de "políticas compensatórias que promovam social e economicamente a comunidade negra”, até meados de 2001 parte significativa das metas do PNDH não haviam sido cumpridas. Contudo, os atos mais simbólicos do que práticos do governo FHC abriram espaço para que organizações da sociedade civil buscassem definir e implementar políticas de ação afirmativa mediante projetos voltados para a educação, mercado de trabalho patrocinados por fundações filantrópicas internacionais, empresas, igrejas, etc. Além disso, ampliou-se o número de órgãos estaduais e municipais voltados para a população negra (Telles, 2003).

A grande guinada no rumo das ações afirmativas no Brasil ocorreu em setembro de 2001, com a Conferência Mundial contra o Racismo, Discriminação Racial, Xenofobia e Formas Correlatas de Intolerância, sob os auspícios da ONU, realizada em Durban, África do Sul. Ela foi precedida por uma série de eventos e relatórios que gradativamente adquiriram visibilidade na mídia envolvendo, sobretudo, diversas agências do Estado brasileiro, políticos, acadêmicos, ONGs, organizações do movimento negro e fundações filantrópicas estadunidenses na denúncia do racismo e das desigualdades raciais no Brasil. Nesse último caso, basta lembrar o exemplo da Fundação Ford que, a partir dos anos 1990, redefine sua orientação científico-política ao privilegiar uma agenda de intervenção social no país (Htun, 2004).

Ainda que a conferência de Durban tenha sido dominada por conflitos entre EUA, Israel e países árabes em torno da velha afirmação de que "o sionismo seria uma forma de racismo", ou sobre os desentendimentos entre países europeus e africanos acerca da escravidão e da reparação, o saldo foi bastante positivo para a rede pró-ação afirmativa no Brasil. Afinal, o documento conclusivo recomendou a adoção dessas políticas (Telles, 2003).

Os efeitos de Durban se fizeram sentir no Brasil de imediato. O governo estava atento a demonstrar, no plano internacional, seu interesse em cumprir resoluções elaboradas em fóruns multilateriais em nome dos princípios da igualdade, inclusive racial, sob o signo dos direitos humanos. 
Logo após a conferência, o governo brasileiro definiu um programa de política de cotas no âmbito de alguns ministérios (Desenvolvimento Agrícola e Reforma Agrária, Justiça e Relações Exteriores) (Moehlecke, 2002). No plano estadual e municipal, diversas iniciativas foram realizadas para a implementação do sistema de cotas. Aquela que obteve maior destaque no final do ano de 2001 foi a da Assembléia Legislativa do Estado do Rio de Janeiro, que estabeleceu uma porcentagem das vagas das universidades estaduais para pretos e pardos (Maggie; Fry, 2004). A partir de 2002, o debate e a implementação de políticas de ação afirmativa com viés racial, com foco no sistema de cotas, estenderam-se por diversas universidades públicas, tanto estaduais como federais. Em sua ampla maioria, com regras variadas, foram definidos mecanismos centrados na autodeclaração dos candidatos. Já a UnB, além de ser a primeira universidade federal a adotar o programa, estabeleceu critérios adicionais à autodeclaração para definir os beneficiários, ou seja, quem seriam os "negros".

\section{Anátomo-psicologia racial: etapas de um processo seletivo}

No início de junho de 2003, em concorrida reunião do Conselho de Ensino, Pesquisa e Extensão (Cepe) da UnB, foi aprovada na íntegra a proposta que destinava uma cota de $20 \%$ das vagas do vestibular para negros. Por 24 votos a favor, um contrário e uma abstenção, o fórum universitário, ao tomar uma decisão de suma importância para os destinos da UnB, contou com a participação, de certo modo inusitada, de personalidades do governo federal (Seabra, 2003). Estavam presentes a ministra-chefe da Secretaria Especial para Políticas de Promoção da Igualdade Racial (Seppir), Matilde Ribeiro, que proferiu uma palestra, e uma representante do Conselho Nacional de Educação (CNE), Petronilha Silva. A mesa foi composta por José Jorge de Carvalho, do Departamento de Antropologia da $\mathrm{UnB}$, e um dos mentores intelectuais da proposta das cotas na UnB; Dione Moura, do Departamento de Comunicação e relatora da Comissão de Implantação do Plano de Metas de Integração Social, Étnica e Racial da UnB; e o vice-reitor da UnB, Timothy Mulholland, que presidiu a reunião. ${ }^{4}$

4 O clima político da reunião do Cepe, incluindo a presença da ministra e da representante do CNE, favoreceu o que Seabra (2003) chamou de "votação inesperada”: “A decisão por votar não estava prevista e foi estimulada pelo debate com a ministra-chefe do Seppir; a professora Petronilha Silva e o professor José Jorge de Carvalho. A platéia, além disso, pediu por algo 
No auditório estavam conselheiros, estudantes e ativistas do movimento negro. Foi nesse clima que a UnB tornou-se a primeira universidade federal a ratificar o sistema de cotas. Durante o evento foi criada uma comissão para implementar a iniciativa (Afonso, 2004b; Seabra, 2003). ${ }^{5}$

Do Plano de Metas para a Integração Social, Étnica e Racial da Universidade de Brasília, elaborado pelos antropólogos José Jorge de Carvalho e Rita Laura Segato e aprovado pela reunião do Cepe, constava no item 3 do capítulo sobre a implementação das cotas a seguinte proposta: "Para fins de acompanhamento do processo de integração racial, será introduzido o quesito cor, tanto por autoclassificação como segundo as categorias do IBGE, nas fichas de registro dos candidatos aprovados” (Carvalho; Segato, 2002, p. 3).

Todavia, essa resolução tomou outro rumo no decurso da execução do projeto cotista sob a direção da Fundação Centro de Seleção e de Promoção de Eventos (Cespe $)^{6}$ da UnB. Órgão técnico-burocrático responsável pela realização de concursos públicos e seleção para o vestibular dentro e fora da UnB, o Cespe, em parceria com a Comissão de Implementação do Plano de Metas para Integração Social, Étnica e Racial na UnB, estabeleceu mecanismos para evitar a ação de supostos "fraudadores raciais". Na visão dos envolvidos no vestibular das raças na $\mathrm{UnB}$, o intuito era de inibir pessoas que pudessem se aproveitar das ambigüidades do cálculo racial brasileiro para “implodir o processo, torná-lo inviável diante da opinião pública”, conforme declaração de José Jorge de Carvalho (Rezende, 2004). Essa preocupação guardava relação com as experiências do sistema de cotas implantado pela Universidade Estadual do Rio de Janeiro (Uerj) e do

mais do que discussão. Quando o debate foi aberto para o público, muitos se manifestaram a favor de uma votação decisiva e imediata. Seguiram-se depoimentos emocionados.”

${ }^{5}$ Conforme Afonso (2004b), "o conselho [Cepe] criou uma comissão formada por cinco professores e uma aluna, integrantes do conselho, além de membros da [ONG] EnegreSer [Coletivo dos Estudantes Negros da UnB] e da deputada distrital pelo PT Érica Kokay, presidente da Comissão de Direitos Humanos da Câmara Legislativa. O grupo ficou responsável por estudar a melhor forma de implementar o sistema. Ele será adotado por dez anos e avaliado constantemente".

${ }^{6}$ De acordo com o Guia do Vestibulando 2º/2004, "o Centro de Seleção e de Promoção de Eventos (Cespe) é o órgão responsável pela realização do PAS [Programa de Avaliação Seriada] e do Vestibular. Também presta serviços para outras universidades e várias empresas e instituições privadas e públicas, federais e estaduais, especialmente na realização de concursos públicos e eventos culturais, avaliações educacionais, seminários, congressos, cursos de formação e consultorias” (Cespe/UnB, 2004c, p. 6). 
programa de ação afirmativa do Instituto Rio Branco, vinculado ao Ministério das Relações Exteriores, que em seus processos seletivos teriam dado margem a que estudantes "burlassem” o projeto político de beneficiar "afro-descendentes". ${ }^{7}$

Destoando de outras universidades federais e estaduais (como a Universidade Federal da Bahia e a Uerj), que implantaram o sistema de cotas por meio unicamente da autodeclaração, a UnB seguiu a trilha aberta pela Universidade Estadual de Mato Grosso do Sul (Uems). A partir do vestibular de 2003, a Uems utilizou fotografias coloridas de 5 por 7 polegadas dos candidatos para fins de identificação dos "negros". Uma comissão constituída por três membros do movimento negro e dois da universidade ficou incumbida de examinar as fotografias para aquilatar quem seria "negro de verdade". Corrêa (2003) informou quanto às estatísticas e procedimentos utilizados na Uems:

[...] entre 530 candidatos que se declararam negros, 76 foram rejeitados porque não possuíam o "fenótipo" exigido, ou seja, "lábios grossos, nariz chato e cabelo pixaim", na definição do presidente do Cedin (Conselho Estadual dos Direitos dos Negros)... Outros 126 foram recusados, pois, embora considerados negros, não eram de escolas públicas ou bolsistas em particulares.

O guia do vestibulando do $2^{\circ}$ vestibular de 2004 da UnB, intitulado Criando Oportunidades para Todos, traz na capa a fotografia de quatro estudantes, aparentemente dois brancos e dois negros. Na apresentação, o reitor Lauro Morhy dá boas-vindas ao candidato e declara que: "Aqui estamos para recebê-lo de braços abertos neste mundo de sonhos e de utopias que impulsionam os avanços do conhecimento e da inovação, e também para desenvolvê-lo no exercício da cidadania”. Declara ainda que “[a] UnB é uma instituição que trabalha para estar à frente de seu tempo...

\footnotetext{
${ }^{7}$ O relato de Matilde Ribeiro, ministra-chefe da Secretaria Especial para Políticas de Promoção da Igualdade Racial (Seppir), é revelador das preocupações que assaltaram a UnB: "No Itamaraty, por exemplo, uma candidata a ingressar pelo sistema de cotas raciais no Instituto Rio Branco, que prepara para a carreira diplomática, quase enganou os examinadores: eriçou os cabelos e cobriu a pele do rosto e dos braços com base escura para passar por negra. Mas se esqueceu daquela faixa da perna que ficou à mostra, branquinha, quando se sentou para a entrevista... é preciso haver um monitoramento constante, assegurar uma averiguação para evitar fraudes. Nas cotas para universidades, por exemplo, todos os que optarem por entrar na seleção terão que ser fotografados.” (Chagas, 2004).
} 
[N]este $2^{\circ}$ Vestibular de 2004, dará mais um passo importante ao adotar a experiência do Sistema de Cotas para Negros, fruto de reivindicação histórica incorporada pela comunidade acadêmica, ciente de sua missão como universidade pública” (Cespe/UnB, 2004a, p. 1).

O edital da "utopia racial" da UnB trazia no item 3.1 a seguinte informação: "Para concorrer às vagas reservadas por meio do sistema de cotas para negros, o candidato deverá: ser de cor preta ou parda; declararse negro(a) e optar pelo sistema de cotas para negro". ${ }^{8}$ O item 3.2 afirmava que: "no momento da inscrição, o candidato será fotografado e deverá assinar declaração específica relativa aos requisitos exigidos para concorrer pelo sistema de cotas para negros". Finalmente, o item 3.3 rezava que: "o pedido de inscrição e a foto que será tirada no momento da inscrição serão analisados por uma Comissão que decidirá pela homologação ou não da inscrição do candidato pelo sistema de cotas para negros” (Cespe/UnB, 2004b).

Por ocasião das inscrições, vários aspectos, de notável simbologia, por enfatizarem uma bem marcada separação entre "negros" e os demais, vieram à tona. A vestibulanda Vanderlúcia Fonseca comentou: “As cotas já são um bom começo. Só acho constrangedor ter que ser fotografada para provar a minha cor. Já tenho isso registrado em meus documentos” (Nunes, 2004). Já Ana Maria Negrêdo frisou diretamente as diferenças de procedimentos: “Acho que os brancos também deveriam tirar foto. Tinha que ser igual para todo mundo. Por que só a gente tem de meter a cara na câmera?” (Inscrição..., 2004). Coube ao fotógrafo incentivar: “Temos que ter jogo de cintura para não deixar a pessoa sem graça, e explicar que é um benefício para ela”. O estabelecimento de filas separadas para as inscrições dos "negros" chamou a atenção. De modo defensivo, declarou o coordenador das inscrições, Neivion Lopes, quanto aos guichês apartados segundo raça: "É separado porque precisamos de espaço reservado para fazer as fotos". Uma senhora teria resmungado baixinho: "Isso é constrangedor" (Meira, 2004a).

8 O sistema de cotas da UnB contempla não somente "negros", como também "índios". Segundo Afonso (2004b), em 12 de março de 2004 foi firmado um convênio entre a UnB e a Fundação Nacional do Índio (Funai). Através desse convênio, “índios” indicados pela Funai e aprovados em um teste de seleção poderão estudar na UnB, com cerca de dez vagas em cada vestibular. Portanto, o status de "índio" não é averiguado através de comissão, como no caso dos "negros", mas previamente chancelado pelo órgão tutor, no caso a Funai. 
O vestibular da UnB transformou-se em uma espécie de "pedagogia racial”, de conversão identitária de pardos e pretos em "negros”, culminando no trabalho da comissão encarregada de identificar os "verdadeiros" beneficiários das cotas. Alguns cenários foram previstos, como aquele antecipado por Dione Moura, relatora da Comissão de Implantação do Plano de Metas de Integração Social, Étnica e Racial da UnB: "Sabemos que haverá casos de irmãos em que um terá a inscrição homologada e outro não” (Castro, 2004a). Por sua vez, Mauro Rabelo, diretor acadêmico do Cespe, atento à precisão dos procedimentos, declarou: "Para garantirmos que a foto não seja distorcida, preocupamo-nos com a qualidade da câmera [digital] e o fundo - que será na cor bege - escolhido para que a imagem não seja alterada”. A seguir, "as fotografias serão armazenadas em CDROM e analisadas por uma comissão, encarregada de evitar abusos ou distorções” (Afonso, 2004a). Romilda Macarini, Diretora Geral do Cespe, afirmou que a comissão responsável pela homologação das candidaturas se basearia no fenótipo dos vestibulandos, ou seja, "Eles devem levar em consideração o tom da pele, o tipo de cabelo e os traços do rosto típicos da raça negra” (Meira, 2004a).

Os responsáveis pelo vestibular da UnB por diversas ocasiões reiteraram que a meta da comissão era o de analisar as características físicas, visando identificar traços da raça negra. Esse objetivo gerou constrangimentos diversos e dilemas identitários de não pouca monta entre os candidatos ao vestibular, devido às dúvidas de se os critérios seriam mesmo o de aparência física (negra) ou de (afro-)descendência. A candidata Ana Paula Leão Paim, a princípio na dúvida sobre se se declararia "negra”, foi convencida pelo argumento da mãe, que lhe disse que sua "tataravó era escrava”. Contudo, ainda assim, Ana Paula estava preocupada pois, segundo ela, "pela fotografia não dá para analisar a descendência”. Outra candidata, Elizabete Braga, que "não se intimidou com a fotografia”, comentou: "Minha irmã não seria considerada negra, por exemplo. Ela é filha de outro pai, tem a pele mais clara e o cabelo mais liso” (Borges, 2004). Ricardo Zanchet, um candidato que se declarou "negro", ainda que "com a pele clara, cabelo liso e castanho... nem de longe lembra[ndo] um negro”, e cuja classificação não foi aceita pela comissão, afirmou: "Vou levar a certidão de nascimento de meu avô e mostrar a eles... Se meu avô e minha bisavó eram negros, eu sou fruto de miscigenação e tenho direito” (Paraguassú, 2004). 
A comissão teve 20 dias para dar o veredicto final sobre os candidatos aptos a concorrerem ao vestibular das cotas. Foi composta, segundo Rabelo, por seis pessoas: "uma estudante, um sociólogo e um antropólogo da UnB, além de três representantes de entidades sociais ligadas ao movimento negro", cujos nomes foram mantidos em sigilo (Meira, 2004b).

Dos 4385 candidatos que se declararam "negros" e, portanto, que concorreram no sistema de cotas, 212 não tiveram suas inscrições homologadas pela comissão. Frisando que "a UnB não quis ser injusta com ninguém”, Rabelo atribuiu o suposto número reduzido de excluídos à perspectiva inclusiva da "banca examinadora”. Em suas palavras, "estipulamos que somente não seria homologado se a decisão fosse unânime contra a inscrição. Bastava um membro da comissão considerar o candidato de cor preta ou parda, que ele tinha a inscrição homologada” (Meira, 2004b). $\mathrm{O}$ diretor acadêmico do Cespe comentou o que considerou uma das maiores dificuldades enfrentadas pela comissão: "O grupo observou traços e tom da pele... A dúvida surgiu entre os pardos mais claros. Tais casos foram discutidos em conjunto. Depois de todos aprovarem as homologações, o grupo fez uma plenária final para analisar todos os não homologados” (Meira, 2004b).

Se a primeira etapa do trabalho de identificação racial da UnB foi conduzido pela equipe da "anatomia racial”, a segunda foi conduzida por um comitê de "psicologia racial". 9 Trinta e quatro dos 212 candidatos com inscrições negadas na primeira etapa entraram com recurso junto à UnB. Uma nova comissão foi formada "por professores da UnB e membros de ONGs”, que exigiu dos candidatos um documento oficial para comprovar a

\footnotetext{
9 Não obstante considerar correto e democrático a autodeclaração por "conferir às pessoas a autonomia sobre sua identidade racial e/ou cultural" ou julgar a fotografia "suspeit[a] do ponto de vista moral porque, ao contrário da autodeclaração, ele rouba o direito à autodefinição", Féres Júnior (2004), ao mesmo tempo, defende a necessidade de constranger as pessoas a não mentirem ou a não praticarem a falsa identificação. Chega a propor uma terceira via, que lembra uma sessão de "psicologia racial", na qual se dispensaria a prova fotográfica, mas se manteria a entrevista. A seu ver: "Uma vez corrigidas as provas, os aprovados dentro do programa de cotas seriam entrevistados, um a um, por profissionais (provavelmente psicólogos) munidos de um questionário desenhado para avaliar sua identidade étnica, incluindo aí sua experiência como objeto de discriminação racial. O questionário não precisa ser complexo, a idéia aqui não é traçar um perfil psicológico dos aprovados, mas sim criar constrangimentos para aqueles que usaram de má-fé na autodeclaração. Ora, uma coisa é mentir ao prencher um formulário, outra muito diferente é sustentar a mentira em uma entrevista. Por fim, caberia aos entrevistadores a avaliação final sobre a veracidade da autodeclaração.”
} 
cor. Foram ainda submetidos à entrevista (gravada, transcrita e registrada em ata) na qual, entre outros tópicos, foram questionados acerca de seus valores e percepções: "Você tem ou já teve alguma ligação com o movimento negro? Já se sentiu discriminado por causa da sua cor? Antes de se inscrever no vestibular, já tinha pensado em você como um negro?” (Cruz, 2004). O candidato Alex Fabiany José Muniz, de 23 anos, um dos beneficiários da nova rodada da seleção das cotas, conseguiu um certificado comprovando que era pardo ao levar a certidão de nascimento e uma foto dos pais. Conforme seu depoimento, "a entrevista tem um cunho altamente político... perguntaram se eu havia participado de algum movimento negro ou se tinha namorado alguma vez com alguma mulata” (Darse Júnior, 2004). Dos 34 candidatos que se submeteram à segunda etapa do exercício de "pedagogia racial”, 21 deles, antes rejeitados, passaram a ser considerados “negros” pela UnB (Para UnB..., 2004).

\section{"Olhos da sociedade" e o apelo à "ciência ordinária"}

Assim que foi publicado o edital do $2^{\circ}$ Vestibular de 2004 da UnB, os antropólogos José Jorge de Carvalho e Rita Segato, principais mentores da iniciativa na instituição, manifestaram júbilo quanto à aprovação da proposta, mas destacaram um ponto de divergência em relação ao encaminhamento do Cespe:

“[...] devemos esclarecer que, diferentemente do procedimento de identificação adotado pela comissão de implantação da UnB, o projeto original que apresentamos não incluía a fotografia do candidato negro e defendia o direito à auto-atribuição racial, seguindo a Convenção 169 da OIT”. (Implantação..., 2004, grifo no original; ver também Rezende, 2004).

O antropólogo Peter Fry, uma das vozes mais críticas das cotas no país, teceu comentários sobre esse júbilo associado a um clima de mal-estar. Para ele, os que agora faziam ressalvas quanto aos procedimentos empregados pela UnB deviam de início ter imaginado que o uso de fotografias era uma direção para a qual o processo poderia resvalar "naturalmente". Segundo Fry, a opção de fotografar os candidatos, por mais intolerável que soe para a moderna antropologia e para outros setores, é logicamente defensável e consistente à luz das idéias de cotas. Isso porque, para fins das cotas, há a necessidade de se identificar e beneficiar aqueles com maiores chances de 
serem discriminados. Ou seja, os que, aos olhos dos discriminadores, apresentem características "mais africanas", no caso do racismo contra negros. Desse modo, a análise das fotografias faria sentido a princípio, dado que "os indivíduos não são discriminados pelo que acham que são, mas pelo que pensam os outros quando os perscrutam e os decodificam social e racialmente" (Fry, 2004). De fato, conforme indicou Dione Moura, o objetivo da comissão seria o de "olhar com os mesmos olhos da sociedade para beneficiar quem realmente deve participar do sistema [de cotas]" (Afonso, 2004b).

Na lógica adotada pelos responsáveis pelo vestibular da UnB, um desafio que se impôs foi o de criar mecanismos que mimetizassem o que poderíamos chamar, a partir da metáfora sugerida por Moura, "os olhos e filtros cognitivos” da sociedade. A difícil tarefa, diga-se de antemão de operacionalização impossível, seria de se chegar a uma "comissão” imbuída desses "olhos e filtros". Nela estariam encapsulados os sentidos de uma coletividade ampla. Seriam as sensibilidades de um cidadão abstrato, mas representativo da sociedade nacional, que no seu dia-a-dia das interações sociais se defronta com outros que pode vir a discriminar com base em um dado conjunto de atributos raciais.

Suponhamos que se chegasse a esses utópicos mecanismos. Ainda assim, as dificuldades não cessariam. O imbróglio passaria a ser que, no Brasil, esses "olhos e filtros" vêem e interpretam as características raciais de diferentes formas, a depender dos contextos nos quais acontecem as interações. Estamos nos referindo à elevada dose de contexto situacional e de ambigüidade que, como amplamente conhecido, marcam as percepções sobre raça no Brasil (sobre esse ponto, ver o clássico estudo de Nogueira, 1955). Como observa Fry (2004), em contraponto ao Brasil, em princípio pode ser mais fácil estabelecer quem é negro ou não em sociedades onde há maior consenso no plano da classificação racial, como África do Sul ou os Estados Unidos.

Conforme já sinalizado, a comissão da UnB foi composta de uma estudante e três representantes do movimento negro, além de um sociólogo e de um antropólogo. Na perspectiva da comissão como "olhos e filtros da sociedade”, poderíamos imaginar que a estudante e as pessoas ligadas ao movimento negro se constituiriam nos "efetivos" representantes da sociedade, ou seja, aqueles cujos sentidos mimetizariam as percepções 
sociais quanto à raça e à discriminação. ${ }^{10}$ Já a posição do antropólogo e do sociólogo, na categoria de especialistas, seria a de monitorar e balizar o processo de classificação, observando se este estaria em consonância com o que seria esperado a partir das evidências geradas pelas ciências sociais em sua longa tradição de estudos sobre raça e relações raciais no Brasil. Se esse foi o arranjo concebido pelos que idealizaram a dinâmica da seleção do vestibular da UnB, qual seja, da existência de papéis diferenciados internamente à comissão, o desenrolar do processo evidenciou uma outra arquitetura.

É interessante notar que, quando certos atores sociais (incluindo os políticos) envolvidos nos debates sobre cotas e ações afirmativas são indagados quanto às notórias dificuldades de classificação racial no Brasil, com freqüência buscam a "mão da ciência". Nessa linha discursiva, a identificação dos potenciais beneficiários das cotas não é apontada como uma barreira, pois haveria "formas científicas" de determinar "quem é negro” no Brasil. Há vários exemplos que podem ser arrolados (ver Santos; Maio, 2004d). Em 2001, o então ministro do Desenvolvimento Agrário do governo Fernando Henrique Cardoso, Raul Jungmann, em uma defesa do programa federal de ação afirmativa, declarou que caso haja dúvidas quanto a um dado indivíduo ser ou não negro, "pode ser submetido a exames”. Por ocasião do último debate na televisão entre os candidatos à presidência da República, em outubro de 2002, Luiz Inácio Lula da Silva foi indagado quanto à política de cota para negros nas universidades federais. Ele respondeu que "a verdade é que você tem forma científica para determinar quem é negro, quem é branco, quem é pardo, quem é amarelo, isso é plenamente possível, esse não seria o problema [para instituir as cotas]” (Fraga, 2002).

Nesses vários casos paira o que poderíamos chamar, na ausência de uma expressão melhor, de uma "visão ordinária da ciência", de teor afim a esquemas taxonômicos de cunho racial que já gozaram de prestígio no passado. Sinaliza-se para conhecimentos e práticas vagos e genéricos, que não chegam mesmo a serem associados diretamente a quaisquer campos ou

10 Dione Moura referiu-se aos “olhos da sociedade”, mas na prática a comissão da UnB, bem menos representativa, tinha metade de seus membros ligados aos grupos mais diretamente vinculados à política de cotas, ou seja, ao movimento negro. 
comunidades de especialistas. Todavia, mesmo que amorfos e sem limites definidos, deles muito se espera. Uma vez colocados os problemas a serem equacionados, sugerem os que esboçam essa visão, conhecimentos e técnicas tornarão disponíveis as ferramentas necessárias para superar as dificuldades.

Retornemos ao caso UnB. Na impossibilidade de viabilizar os tais "olhos e filtros cognitivos", e diante da necessidade de revestir com uma película de objetividade os procedimentos de classificação racial (afinal, tratava-se de um edital para concurso público de grande dimensão), o processo seletivo também resvalou para uma "visão ordinária da ciência". Contudo, se no discurso dos políticos é possível se manter no plano das generalidades, na práxis da implantação da política pública o "ordinário" precisa se materializar em entidade concreta e delimitada. No caso do vestibular da UnB, a "ciência ordinária" efetivou-se em uma "antropologia das raças".

Nessa "antropologia das raças”, o papel do antropólogo esteve longe daquele de monitoramento ou balizamento da dinâmica de classificação para fins de homologação racial. Conforme divulgado pela imprensa, de modo a ser inclusiva, decidiu-se que bastava que um dos membros identificasse o candidato como "negro" para que ele fosse certificado como tal pela comissão. Assim, menos que papéis diferenciados, os diversos membros da comissão tiveram suas atuações equacionadas em um mesmo plano, com as diversas vozes com igual "poder" de atribuição ou negação da "identidade negra" a um determinado indivíduo. Ainda que todo o processo da UnB discursivamente ressalte as pontes com a sociedade civil (através da presença de representantes do movimento negro na comissão, por exemplo), e portanto a "natureza democrática” da iniciativa - a partir da aliança singular entre cientistas sociais, representação estudantil e movimento negro ${ }^{11}$ - na prática verificou-se um processo de "racialização pelo alto" (Azevedo, 2004, p. 215), comandado pelo aparelho universitário em nome da “discriminação positiva”. ${ }^{12}$

${ }^{11}$ Chama a atenção que lideranças do movimento negro, que em várias ocasiões se manifestaram contra sugestões ou tentativas por parte do governo ou de outras instâncias para fins do estabelecimento de critérios para classificação racial que não se embasassem unicamente na autodeclaração - ver, por exemplo, caso detalhado em Santos e Maio (2004d, p. 82) -, não se pronunciaram ou chegaram mesmo a apoiar a iniciativa de estabelecer a comissão de homologação da identidade racial por parte da UnB (ver Carneiro 2004a, 2004b; Castro, 2004b).

$12 \mathrm{O}$ mais recente edital de vestibular da UnB, preparado pelo Cespe e referente ao primeiro vestibular de 2005, mantém o procedimento de autodeclaração, seguido de fotografia daqueles que se declararam negros (pretos ou pardos) e análise das imagens por uma banca (novo 


\section{Antropólogos, perícia e o fazer antropológico}

Considerando a história recente da antropologia no Brasil, um contraponto que pode ser estabelecido com o caso das cotas na UnB é aquele de antropólogos enquanto peritos em processos judiciais e administrativos sobre terras indígenas e, mais recentemente, terras quilombolas. Sem pretender entrar em maiores detalhes, pode-se dizer que o envolvimento da comunidade antropológica com essa questão data de 1988, quando a Procuradoria Geral da República estabeleceu um convênio com a Associação Brasileira de Antropologia (ABA). No âmbito desse convênio, profissionais indicados pela ABA passaram a ser contratados (envolvendo remuneração) com vistas à condução de perícias e à geração de laudos que substanciem provas e argumentos, de cunho antropológico, de modo a servirem de subsídios para decisões por parte de juízes em questões envolvendo povos indígenas (Oliveira, 2002; Silva; Luz; Helm, 1994).

A participação de antropólogos em atividades de perícia tem sido objeto de várias análises, com muitos dos autores refletindo sobre as conseqüências dessa inserção no plano do "fazer antropológico" (Arruti 2003; Dal Poz Neto, 1994; Lopes da Silva, 1994; Oliveira, 2002; Silva; Luz; Helm, 1994; entre outros).

Em um conjunto de textos sobre a posição dos antropólogos enquanto peritos nesses processos judiciais e administrativos, João Pacheco de Oliveira (2002, p. 257) revela-se preocupado com o "conjunto de tarefas e expectativas que estão sendo atribuídas aos antropólogos”. Indaga logo na abertura de seu texto:

Cabe ao antropólogo decidir se um indivíduo ou uma coletividade podem ser caracterizados como "indígenas"...? Enquanto especialista, ele possui instrumentos conceituais e metodológicos necessários para tal definição? Em termos epistemológicos e éticos, ele deve tomar uma tal decisão [...] colocando-se na condição de árbitro entre interesses sociais opostos ou mesmo antagônicos? (Oliveira 2002, p. 253). ${ }^{13}$

termo, em substituição à comissão) para fins de homologação ou não da inscrição. Houve ainda outra "sutil” alteração: na nova seleção "declarar-se negro" vem antes do candidato optar pela “cor preta ou parda” (Cespe/UnB, 2004c). Já surgiu uma estatística significativa desse novo vestibular: houve aumento na cifra de vestibulandos (de 4,8\% para 15,8\%) que não tiveram sua autoclassificação homologada pela comissão (Sai lista..., 2004; Santos; Maio, 2004c).

13 O texto de Oliveira (2002) é uma versão mais detalhada e atualizada de trabalhos anteriores do autor sobre o mesmo tema (Oliveira, 1994, 1999). 
Como bem ressalta Oliveira (2002), na moderna reflexão das ciências sociais, as identidades étnicas e raciais são concebidas como derivadas de contextos situacionais, algumas vezes em constante fluxo (Barth, 1997; Eriksen, 1993; Jenkins, 1997). Em decorrência, menos que limites rígidos e precisos, a ênfase reside em abordagens antiessencialistas, dado que "[as] classificações realizadas por diferentes sujeitos sociais podem variar não apenas no valor atribuído aos termos, mas também quanto ao próprio recorte desses elementos e na definição da natureza dos níveis de inclusão" (Oliveira, 2002, p. 260-261).

A propósito, como apontam diversas análises (Lopes da Silva, 1994; Oliveira, 2002), residem na definição e na percepção quanto às identidades um dos pontos de maior tensão entre antropólogos e juízes (ou antropologia e direito, para nos referirmos aos campos disciplinares). Se para os antropólogos as identidades podem estar em constante construção e remodelação, a expectativa dos juízes é quanto a formatações discretas e precisas. Assim, da parte do direito, a expectativa do "fazer antropológico" em situações de perícia seria o de gerar taxonomias não muito diferentes, em conceito, às tipologias comuns às ciências naturais:

Tal como os estudiosos da natureza são capazes de produzir, pela morfologia de animais e plantas, a identificação e a classificação de um exemplar do mundo natural, também o antropólogo deveria ser um especialista capaz de identificar e classificar, pelas formas culturais adotadas, os homens concretos dentro das unidades sociais a que pertenceriam. (Oliveira, 2002, p. 259).

Portanto, preocupa sobremaneira Oliveira que, diante do contexto jurídico ou administrativo de uma situação de perícia, o antropólogo passe a agir como um "classificador de identidades”. Para além disso, pelo lugar simbólico (e prático) que ocupa devido ao status de perito, a percepção do antropólogo quanto à identidade do sujeito da pesquisa passa a assumir "ares de verdade":

[...] o antropólogo estará entrando no jogo da disputa por classificações sociais, servindo-se de uma posição assimétrica (a de perito) para impor sua proposta frente aos demais atores. Ele estará, desse modo, cedendo a uma dupla ilusão: por um lado, sucumbindo à sedução de falar a partir de uma posição de poder, abandonando o campo que lhe é próprio; por outro lado, estará cometendo a ingenuidade sociológica de imaginar que, através de sua proposta, esteja falando algum grupo ou força social. (Oliveira, 2002, p. 270). 
A conclusão de Oliveira é que a participação dos antropólogos nesses processos, importante e imprescindível, deve se cercar de algumas "reformulações" de modo a preservar, o mais possível, a reflexão e a prática antropológica. Para tanto, sugere modificações no contexto do trabalho do perito com vistas a "afastá-lo de um cenário primordialmente de decisão e intermediação política... buscando aproximá-lo, inversamente, mais do 'encontro' que caracteriza uma situação etnográfica”' (Oliveira, 2002, p. 271, grifo do autor).

Essa breve incursão nas reflexões sobre as interfaces entre antropologia e contexto de perícia traz subsídios úteis para se pensar a presença de um antropólogo no processo seletivo do vestibular de cotas da UnB.

Isso porque muitas das situações com as quais se defrontam os antropólogos em ambos os contextos apresentam paralelos marcantes. Dentre esses podem ser mencionados a participação em processos atrelados à produção (ou revelação/ confirmação) de identidades; horizontes de expectativas distintos entre cientistas sociais, por um lado, e advogados e juízes, por outro, imputando-se aos primeiros o papel de classificador/ taxonomista; e, finalmente, posição assimétrica na dinâmica de produção de identidades, com a "visão" do antropólogo sobrepujando ou suplantando àquela dos demais atores sociais, incluindo os "nativos". Como veremos adiante, esses pontos, em menor ou maior grau, mostraram-se proeminentes nas reações que o vestibular de cotas da UnB vieram a despertar.

\section{Legitimação e objetividade através da ciência}

A comissão da UnB, constituída por cientistas sociais, representantes de entidades do movimento negro e uma estudante universitária, foi estabelecida com o objetivo de conduzir uma atividade técnico-burocrática, ou seja, homologar ou não a auto-atribuição pelo candidato do status de "negro". Essa operação estaria embasada em conhecimento considerado científico no escrutínio de características como cor da pele, textura do cabelo, formato do nariz, etc., discerníveis a partir do exame das fotografias, com vistas à classificação racial. A presença na comissão de membros do movimento negro estaria coerente com o processo de construção de identidades, afeito à "pedagogia racial” introduzida no vestibular da UnB. Contudo, essa representação por si só não garantia a legitimidade dessa 
comissão, que demandava a autoridade da ciência, ainda mais em um espaço universitário. A dimensão de cientificidade incluía a presença de "especialista em raça”, no caso representado pelo antropólogo, alçado à condição de repositório de conhecimentos e técnicas da classificação racial. Nessa situação, poderia se aventar a hipótese de que a presença de cientistas sociais especializados em análises de dinâmicas identitárias afinadas com as "políticas de identidade", que norteariam a ação dos movimentos sociais, permitiria atender aos requisitos ditados pelo programa da UnB.

Todavia, a afinidade entre racionalidade administrativa e racionalidade científica, própria a dominação burocrática moderna, como nos lembra Weber (1991), na versão do aparato Cespe-UnB não foi bem recebida. A estratégia de estabelecer a comissão, bem como a tarefa que lhe foi incumbida, atraiu um volume considerável de críticas, como já assinalado. Além do questionamento do porquê não se ater à autodeclaração, argumentou-se que os procedimentos apresentavam similaridades com práticas pretéritas e cientificamente superadas. Por um lado, a comissão buscou se legitimar através da aplicação de critérios supostamente objetivos e científicos; por outro, na visão dos críticos, apoiou-se em uma cientificidade anacrônica e alheia aos preceitos da ciência contemporânea.

Em junho de 2004, a Comissão de Relações Étnicas e Raciais da Associação Brasileira de Antropologia (Crer-ABA) emitiu um posicionamento acerca dos procedimentos adotados pela UnB. Lê-se:

A pretensa objetividade dos mecanismos adotados pela UnB constitui, de fato, um constrangimento ao direito individual, notadamente ao da livre autoidentificação. Além disso, desconsidera o arcabouço conceitual das ciências sociais, e, em particular, da antropologia social e antropologia biológica. A Crer-ABA entende que a adoção do sistema de cotas raciais nas Universidades públicas é uma medida de caráter político que não deve se submeter, tampouco submeter aqueles aos quais visa beneficiar, a critérios autoritários, sob pena de se abrir caminho para novas modalidades de exceção atentatórias à livre manifestação das pessoas [...] a [Crer-ABA] externa a sua preocupação não somente com os fundamentos que norteiam o sistema classificatório dos candidatos, como também com as repercussões negativas que o sistema implantado pela UnB poderá produzir. (Crer-ABA, 2004). ${ }^{14}$

\footnotetext{
${ }^{14}$ No calor das críticas ao processo de implantação das cotas na UnB, e particularmente logo em seguida ao posicionamento da Comissão de Relações Étnicas e Raciais da Associação Brasileira de Antropologia (Crer-ABA), Jaques Jesus, psicólogo formado pela UnB, circulou no site de discussão Discriminação Racial (disponível em: <http://br.groups.yahoo.com/group/
} 
O documento da Crer-ABA pode ser interpretado como uma manifestação que, em nome de uma comunidade composta de antropólogos com variadas especialidades (há referência à antropologia social e à antropologia biológica), problematiza fontes e loci de autoridade/ competência científica (ver Bourdieu, 1983). Dado que congrega centenas de profissionais da área da antropologia no Brasil, portanto revestindo-se de espessa camada de legitimidade para se manifestar em assuntos científicos ligado à raça, com o capital simbólico transferido a partir de sua instância geradora (qual seja, a ABA), o posicionamento da Crer é uma peça argumentativa que procura solapar a base de autoridade/competência científica da comissão da UnB, já que “desconsidera o arcabouço conceitual das ciências sociais". ${ }^{15}$

Não foi somente a ABA que utilizou seu capital de prestígio e de reconhecimento na disputa sobre o monopólio quanto à (in)determinação de quem é "negro" no Brasil. Para ilustrar esse ponto, exploraremos brevemente o conteúdo do artigo dos geneticistas Sérgio Pena e Maria Cátira Bortolini, com o provocativo título Pode a genética definir quem deve se beneficiar das cotas universitárias e demais ações afirmativas?

Os geneticistas abrem o trabalho situando a posição da genética frente à questão das raças: "as raças humanas simplesmente não existem do ponto de vista biológico” (Pena; Bortolini, 2004, p. 31). A seguir, discorrem sobre

discriminacaoracial/>), em 11 de junho de 2004, uma mensagem (n. 11697) que continha comentários de Rita Segato, uma das formuladoras da proposta de cotas da UnB e professora do Departamento de Antropologia, e também do vice-reitor Timothy Mulholland. O vicereitor, no que se refere aos procedimentos da UnB, mostrou-se preocupado com as repercussões do documento da ABA que, a seu ver, "certamente engrossará os argumentos das ações judiciais” contra o sistema de cotas da UnB. Segato, por sua vez, critica duramente o posicionamento da Crer-ABA, mas também não deixa de apontar o que considera equívocos do processo das cotas pelo aparato Cespe/UnB. Ao contrapor conhecimento antropológico à lógica burocrática, Segato, sem subterfúgios, declara: "se vocês da administração da UnB tivessem escutado adequada e respeitosamente o que nós, após anos de estudo e reflexão sobre o tema, tínhamos para lhes transmitir no processo de implantação da política, teriam evitado para vocês e para a UnB os constrangimentos pelos que, neste momento, estamos passando. Agora, somente fica a lamentar que, mais uma vez, a cobiça afobada dos ambiciosos tenha saído tão cara para a imagem da instituição. Nada a fazer.”

${ }^{15}$ Uma outra crítica à declaração da Crer-ABA partiu da Educafro, ONG sediada em São Paulo e ativa defensora do sistema de cotas (Educafro, 2004). Entre outros pontos, a assertiva da Crer-ABA de que o sistema adotado pela UnB seria autoritário foi rebatido no documento: "A liberdade individual dos que se auto-identificam como afro-descendentes não está sendo atentada”. O que não é mencionado nos comentários da Educafro é que a comissão da UnB tinha o poder de discordar e até mesmo invalidar a auto-identificação dos candidatos para fins de inscrição no sistema de cotas.

Horizontes Antropológicos, Porto Alegre, ano 11, n. 23, p. 181-214, jan/jun 2005 
temas como a origem do Homo sapiens e a ocupação do continente americano para, adiante, ilustrar como a moderna genética molecular pode ser útil na compreensão dos processos de origem e dispersão das populações humanas no mundo. O cerne do argumento repousa no quadro da composição genética da população brasileira delineado pelas pesquisas genéticas. Os autores argumentam que a proporção de pessoas com ancestralidade genômica africana no Brasil é extremamente elevada, de modo que a maioria dos brasileiros é composta de afro-descendentes do ponto de vista genômico. Entre as várias conclusões, ressaltam que $86 \%$ da população brasileira apresenta mais de $10 \%$ de ancestralidade africana e que $48 \%$ dos afro-descendentes no Brasil se classificam como "brancos".

Num anticlímax, particularmente se considerarmos a contundência da indagação que constitui o título do trabalho, concluem os autores:

Tendo em vista a nova capacidade de se quantificar objetivamente, por meio de estudos genômicos, o grau de ancestralidade africana de cada indivíduo, pode a genética definir quem deve se beneficiar das cotas universitárias e demais ações afirmativas? Prima facie poderia parecer que sim, mas a nossa resposta é um enfático NÃO... Acreditamos que a genética moderna pode oferecer subsídios para as decisões políticas e que o perfil genético da população brasileira certamente deve ser levado em conta em decisões políticas. Por outro lado, a genética não pode arrogar-se um papel prescritivo explícito. (Pena; Bortoloni, 2004, p. 46).

O texto Pode a genética definir quem deve se beneficiar das cotas e demais ações afirmativas?, ao contrário do documento da Crer-ABA, não foi concebido ou divulgado como um posicionamento direto em relação ao caso UnB. Não obstante, além da sobreposição temporal (foi publicado em meados de 2004, no "calor da hora” dos debates sobre a comissão), de modo explícito aborda questões referentes à capacidade, competência e autoridade científica quanto a se posicionar sobre questões ligadas à definição racial e aplicação da política de cotas. Pena e Bortolini mencionam logo no início do texto que instituições de ensino utilizaram a categoria de “afro-descendência” para fins da identificação dos possíveis beneficiários da política de cotas (como a Universidade Estadual de Mato Grosso do Sul) e que o artigo pretende "fornecer subsídios para este tema usando o instrumental da genética molecular e da genética de populações para discutir a contribuição africana para a formação da população brasileira” (Pena; Bortolini, 2004, p. 33). 
Por um lado, os geneticistas colocam de forma incisiva que, no plano científico, a genética de populações constitui-se em um campo revestido da competência e autoridade para tratar da questão racial. Contudo, menos que atuar no sentido de reforçar a validação, é uma autoridade que esvazia bases conceituais, uma vez que enfatiza que "raça" é um conceito que, do ponto de vista biológico, não se aplica para a espécie humana. Além dessa desconstrução da noção, a argumentação derivada da genética, e enfatizada pelos dois autores, é que há uma marcante dissociação entre fenótipo e genótipo, ou seja, no Brasil, aparência física é um preditor fraco quanto à descendência, seja européia ou africana (ver Parra et al., 2003). Assim, Pena e Bortolini (2004), a partir de uma posição revestida pela autoridade discursiva da genética molecular, secundarizam cientificamente quaisquer tentativas de classificação racial ou de definição de critérios de afrodescendência (biológica) através da morfologia. ${ }^{16}$

\section{Consideracões finais}

A comissão de identificação racial da UnB operou uma ruptura com uma espécie de "acordo tácito" que vinha vigorando no processo de implantação do sistema de cotas no país, qual seja, o respeito à autoatribuição de raça no plano das relações sociais. A valorização desse critério, próprio das sociedades modernas e imprescindível em face da fluidez racial existente no Brasil, cai por terra a partir das normas estabelecidas pela UnB. Os defensores do sistema da UnB contraargumentam que é preciso controlar os alegados "fraudadores raciais", aqueles que se dirão "negros” somente para usufruir do benefício das cotas. Cabe lembrar que a ampla maioria das instituições que adotaram as cotas no país tem preferido depender unicamente da autodeclaração. Possivelmente avaliam que os custos sociais e históricos de implantar um "tribunal racial", como foi rotulado o sistema da UnB, podem ser por demais elevados a médio e a longo prazo. A Academia Brasileira de Ciências (ABC), em documento sobre a reforma universitária no país, considera que

${ }^{16}$ Segundo Nunes (2004), professores da área de ciências biológicas da UnB manifestaram preocupação quanto aos procedimentos de classificação adotados pela UnB, enfatizando, tal como Pena e Bortolini (2004), a intensa mistura genética da população brasileira, pois muitos carregam "herança negra". 
"não devemos enfrentar manifestações de preconceito racial existentes na sociedade brasileira com critérios de inspiração racial ou mesmo racista, destituídos de qualquer base científica, dando margem a distorções, manipulações de toda espécie e acirramento de tensões claramente danosas à vida universitária” (Academia Brasileira de Ciências, 2004).

De forma contundente, o caso UnB aponta para uma íntima articulação entre movimentos sociais, academia e instâncias governamentais na inédita inserção da política de cotas raciais em uma universidade pública federal. Simbólica e politicamente proeminente, trata-se da implantação de um sistema de cotas em instituição de ensino superior localizada na capital federal, a poucos quilômetros das sedes dos poderes executivo, legislativo e judiciário. Essa próxima associação fez que com que, como detalhamos, a sessão de apreciação da proposta de implementação de cotas da UnB, que aconteceu no âmbito de uma reunião do Conselho de Ensino, Pesquisa e Extensão (Cepe), congregasse esses diversos setores. Além de representantes da comunidade universitária e do movimento negro, estava presente a ministra-chefe da Secretaria Especial para Políticas de Promoção da Igualdade Racial (Seppir), Matilde Ribeiro. Portanto, talvez mais que um microcosmo, o processo de implantação das cotas raciais da UnB teve um caráter de "exemplaridade", de "vitrine" para a sociedade como um todo.

A experiência da UnB revela ainda a intrincada questão do acionamento de conhecimentos e técnicas pelas agências e agentes da administração pública. Em particular, sobressaem as modalidades de representação e apropriação do conhecimento antropológico por parte do aparato burocrático da UnB envolvido no vestibular das cotas. Argumentamos que, por varias razões, a "antropologia das raças”, peça de engenharia tecnoburocrática criada para dar objetividade ao processo seletivo da UnB, mostrou-se ser uma entidade potencialmente geradora de fortes tensões no cenário da antropologia contemporânea. Ao se colocar um antropólogo na comissão, designando-o como "especialista no tema”, houve o estabelecimento de pontes diretas entre antropologia e atividades de classificação racial a partir de atributos corporais com ares do que constituía a identidade da antropologia física que se praticava no final do século XIX e no início do século XX. Além do que, a antropologia é associada a uma ciência que teria a capacidade de descobrir e/ou atribuir aos indivíduos “identidades” e, não menos importante, refrear o ímpeto de "fraudadores” ou “transgressores” em matéria de pertencimento racial. A dupla dose tipologia- 
prescrição não goza de prestígio na moderna reflexão antropológica. Conforme comentou o então presidente da Associação Brasileira de Antropologia, Gustavo Lins Ribeiro,

O que é difícil de ser aceito por antropólogos é a desconsideração do princípio de autodeterminação das identidades sociais e étnicas [...] Pelo método mais precário, o do reconhecimento do fenótipo, acaba-se alimentando estereótipos segundo os quais negros são os que têm cor, nariz, boca e cabelo de determinada forma. Tarefa que, como se sabe, no Brasil, pode ser altamente ingrata e que, ao longo do século XX, afundou muitas boas intenções, inclusive na antropologia. (Ribeiro, 2004).

O vestibular das cotas da UnB envolveu também disputas em torno da autoridade/legitimidade de se abordar questões ligadas à raça e à classificação racial. De forma independente, mas com algum grau de sobreposição, antropólogos e geneticistas questionaram, a partir de diferentes vertentes, a legitimidade do arsenal de conhecimentos e técnicas acionados pela comissão da UnB. Pode-se afirmar que, na reatualização da atuação do Estado frente à questão racial no Brasil, as modalidades através das quais a ciência foi acionada gerou ações e reações que transbordaram para muito além do contexto imediatamente próximo do processo seletivo.

Nas mais diversas esferas da sociedade brasileira, seja no tocante à educação, à saúde ou às condições socioeconômicas, é evidente que há iniqüidades no plano étnico-racial que precisam ser combatidas. A luta contra o racismo vem ocupando posição proeminente no debate político contemporâneo. Se há consenso quanto à existência e à relevância do problema, o cerne dos debates centra-se nas formas de enfrentamento. Quanto à educação superior, há desde posições que privilegiam a necessidade de melhoria do ensino básico e médio de modo a melhor nivelar as condições de acesso, até propostas mais centradas na implementação de cotas raciais, o que foi inaugurado pela Uerj. Entre esses pólos, há um amplo leque de proposições que, em graus variados, contempla projetos universalistas ou políticas focais.

Na luta anti-racista, em que se considera "raça" como uma construção social e como um instrumento de libertação da opressão racial, sob o aval da ação estatal, corre-se o perigo de se enveredar pela construção de categorias essencializadas, fixas, próprias ao poder normativo das leis, aos desígnios das políticas públicas. Por contemplar vários desses elementos, o 
caso da UnB, cujos procedimentos de classificação racial para ingresso através do vestibular continuam em vigor, constitui um debate obrigatório.

\section{Referências}

ACADEMIA BRASILEIRA DE CIÊNCIAS. Propostas da Academia Brasileira de Ciências para debate sobre reforma da Universidade. Jornal da Ciência, Rio de Janeiro, 2004. Disponível em: <http:// www.jornaldaciencia.org.br/Detalhe.jsp?id=19703>. Acesso em: 3 jul. 2004. AFONSO, I. Inscreva-se no vestibular. UnB Agência, Brasília, 8 abr. 2004a. Disponível em: <http://www.unb.br/acs/> . Acesso em: 21 nov. 2004. AFONSO, I. Cotas: política urgente. UnB Agência, Brasília, 12 maio 2004b. Disponível em: <http://www.unb.br/acs/>. Acesso em: 21 nov. 2004.

ARRUTI, J. A. Etnografia, história e memória no Mocambo: notas sobre uma "situação de perícia". 2003. Mimeografado.

AZEVEDO, C. M. M. Cota racial e estado: abolição do racismo ou direitos de raça? Cadernos de Pesquisa, São Paulo, v. 34, n. 121, p. 213-239, 2004. BARTH, F. Grupos étnicos e suas fronteiras. In: POUTIGNAT, P.; STRIFFFENART, J. (Org.). Teorias da etnicidade. São Paulo: Unesp, 1997. p. 187-227.

BORGES, P. Sistema atrai 4,4 mil candidatos. Correio Braziliense, Brasília, p. 31, 18 abr. 2004.

BOURDIEU, P. O campo científico. In: ORTIZ, R. (Org.). Pierre Bourdieu. São Paulo: Ática, 1983. p. 122-155.

CARDOSO, F. H. Capitalismo e escravidão no Brasil meridional. São Paulo: Difusão Européia do Livro, 1962.

CARNEIRO, S. UnB. Correio Braziliense, Brasília, p. 11, 5 abr. 2004a.

CARNEIRO, S. Negros de pele clara. Correio Braziliense, Brasília, p. 11, 29 maio 2004b.

CARVALHO, J. J. As ações afirmativas como resposta ao racismo acadêmico e seu impacto nas ciências sociais brasileiras. Brasília: UnB, Departamento de Antropologia, 2004. (Série Antropologia, 358).

CARVALHO, J. J.; SEGATO, R. L. Plano de metas para a integração social, étnica e racial da Universidade de Brasília. 2002. Mimeografado. 3 p. 
CASTRO, A. A. O sistema de cotas na prática. UnB Agência, Brasília, 18 maio 2004a. Disponível em: <http://www.unb.br/acs/>. Acesso em: 21 nov. 2004.

CASTRO, A.A. Aparência determina o preconceito. UnB Agência, Brasília, 22 out. 2004b. Disponível em: <http://www.unb.br/acs/>. Acesso em: 21 nov. 2004. CESPE/UnB. Guia do Vestibulando 2/2004: criando oportunidades para todos. Brasília, 2004a. 106 p.

CESPE/UnB. Edital $n^{o}$ 3/2004 - 2a․ vestibular 2004, de 18 de março de 2004. Brasília, 2004b.

CESPE/UnB. Edital no 2/2004 - 1ㅁ: vestibular 2005, de 6 de setembro de 2004. Brasília, 2004c.

CHAGAS, H. Vem aí o Estatuto Racial. O Globo, Rio de Janeiro, p. 3, 21 mar. 2004.

CONTINS, M.; SANTANA, L. C. O movimento negro e a questão da ação afirmativa. Estudos Feministas, v. 4 , n. 1, p. 209-220, 1996.

CORRÊA H. Em MS, foto diz quem entra por cotas. Folha de São Paulo, São Paulo, p. C-3, 15 dez. 2003.

CRER-ABA. Posicionamento da Comissão de Relações Étnicas e Raciais da Associação Brasileira de Antropologia sobre o Sistema de Cotas da UnB. 2004. Disponível em: <http://www. abant.org.br/ informacoes/documentos/documentos_028.shtml>. Acesso em: 17 set. 2004. CRUZ, N. H. Alunos são reavaliados pela UnB para ingresso no sistema de cotas. Folha de São Paulo, São Paulo, p. D-3, 7 jun. 2004.

DAL POZ NETO, J. Antropólogos, peritos e suspeitos: questões sobre a produção da verdade judicial. In: SILVA, O. S.; LUZ, L.; HELM, C. M. (Org.). A perícia antropológica em processos judiciais. Florianópolis: Editora da UFSC, 1994. p. 53-59.

DARSE JÚNIOR. Concorrência maior. Correio Braziliense, Brasília, p. 31, 23 jun. 2004.

DINIZ, D.; MEDEIROS, M. A igualdade das cotas. Jornal de Brasília, Brasília, 20 abr. 2004. Disponível em: <http://www.jornaldebrasilia.com.br/> . Acesso em: 22 abr. 2004.

EDUCAFRO. Carta aberta à Comissão de Relações Étnicas e Raciais da Associação Brasileira de Antropologia. São Paulo, 9 jun. 2004. Mimeografado. 
ERIKSEN, T. H. Ethnicity and nationalism: anthropological perspectives. London: Pluto Press, 1993.

FÉRES JÚNIOR, J. Um mal social. O Globo, Rio de Janeiro, p. 7, 20 abr. 2004.

EDITORIAL: cotas econômicas. Folha de São Paulo, São Paulo, p. A2, 11 abr. 2004.

FRAGA, P. PT detecta arrogância e ironia em Lula na TV. Folha de São Paulo, São Paulo, 5 out. 2002. Caderno Especial, p. 3.

FRY, P. Politics, nationality, and the meanings of "race" in Brazil. Daedalus: Journal of the American Academy of Arts and Sciences, n. 129, p. 83-118, 2000.

FRY, P. A lógica das cotas raciais. O Globo, Rio de Janeiro, p. 7, 14 abr. 2004.

GÓES, J. R. P. Cotas, um remédio que é veneno. O Estado de São Paulo, São Paulo, 13 abr. 2004. Disponível em: <http://www.estado.com.br>. Acesso em: 18 abr. 2004.

GONZALEZ, L. O movimento negro na última década. In: GONZALES, L.; HASENBALG, C. A. (Org.). Lugar de negro. Rio de Janeiro: Marco Zero, 1982. p. 9-66.

GRIN, M. Esse ainda obscuro objeto de desejo: políticas de ação afirmativa e ajustes normativos: o seminário de Brasília. Novos Estudos Cebrap, n. 59, p. 193-202, 2001.

GRIN, M. Você é a favor da cota para negros? Não. Correio Braziliense, Brasília, p. 30, 18 abr. 2004a.

GRIN, M. Auto-confrontação racial e opinião: o caso brasileiro e o norteamericano. Interseções: Revista de Estudos Interdisciplinares, ano 6, n. 1, p. 95-117, 2004b.

HASENBALG, C. Discriminação e desigualdades raciais no Brasil. Rio de Janeiro: Graal, 1979.

HASENBALG, C. Entre o mito e os fatos: racismo e relações raciais no Brasil. In: MAIO, M.C.; SANTOS, R. V. (Org.). Raça, ciência e sociedade. Rio de Janeiro: Fiocruz, 1996. p. 235-249.

HTUN, M. From "racial democracy” to affirmative action: changing state policy on race in Brazil. Latin American Research Review, v. 39, n. 1, p. 60-89, 2004. 
IMPLANTAÇÃO do sistema de cotas para estudantes negros e indígenas na UnB. [esclarecimentos dos professores José Jorge de Carvalho e Rita Laura Segato]. Notícias da Comunidade Virtual de Antropologia, n. 15, 22 mar. 2004. Disponível em: <http://www.antropologia.com.br/comu/ comu15.html>. Acesso em: 21 nov. 2004.

INSCRIÇÃO por cotas até hoje na UnB. Jornal de Brasília, Brasília, 17 abr. 2004. Disponível em: <http://www.jornaldebrasilia.com.br/>. Acesso em: 22 abr. 2004.

JENKINS, R. Rethinking ethnicity: arguments and exploitations. London: Sage, 1997.

LOPES DA SILVA, A. Há antropologia nos laudos antropológicos? In: SILVA, O. S.; LUZ, L.; HELM, C. M. (Org.). A perícia antropológica em processos judiciais. Florianópolis: Editora da UFSC, 1994. p. 60-66.

MAGGIE, Y.; FRY, P. A reserva de vagas para negros nas universidades brasileiras. Estudos Avançados, v. 18, n. 50, p. 67-80, 2004.

MAIO, M. C. Negros e judeus no Rio de Janeiro: um ensaio de movimento pelos direitos civis. Estudos Afro-Asiáticos, n. 25, p. 161-188, 1993.

MAIO, M. C. Unesco and the study of race relations in Brazil: national or regional issue? Latin American Research Review, v. 36, n. 2, p. 118-136, 2001.

MEIRA, L. Um teste de cor. Correio Braziliense, Brasília, p. 23, 13 abr. 2004a.

MEIRA, L. Rejeitados por unanimidade. Correio Braziliense, Brasília, p. 24, 1 jun. 2004b.

MOEHLECKE, S. Ação afirmativa: história e debates no Brasil. Cadernos de Pesquisa, São Paulo, n. 117, p. 197-217, 2002.

MULHOLLAND, T. Igualdade de oportunidade na UnB. O Globo, Rio de Janeiro, p. 7, 19 abr. 2004a.

MULHOLlAND, T. Cotas: por um debate sério. Correio Braziliense, Brasília, p. 13, 21 jun. 2004b.

NOGUEIRA, O. Preconceito racial de marca e preconceito racial de origem (Sugestão de um quadro de referência para a interpretação do material sobre relações raciais no Brasil). In: ANAIS do XXXI Congresso Internacional dos Americanistas. São Paulo: Anhembi, 1955. p. 409-434. 
NUNES, J. C. Vestibular polêmico. Correio Braziliense, Brasília, p. 14, 12 abr. 2004.

OLIVEIRA, J. P. Os instrumentos de bordo: expectativas e possibilidades do trabalho do antropólogo em laudos periciais. In: SILVA, O. S.; LUZ, L.; HELM, C. M. (Org.). A perícia antropológica em processos judiciais. Florianópolis: Editora da UFSC, 1994. p. 115-139.

OLIVEIRA, J. P. Ensaios de antropologia histórica. Rio de Janeiro: Editora UFRJ, 1999.

OLIVEIRA, J. P. O antropólogo como perito: entre o indianismo e o indigenismo. In: L’ESTOILE, B; NEIBURG, F.; SIGAUD, L. (Org.). Antropologia, impérios e Estados nacionais. Rio de Janeiro: RelumeDumará: Faperj, 2002. p. 253-277.

PARA UnB, 21 rejeitados agora são negros. Folha de São Paulo, São Paulo, p. C-5, 23 jun. 2004.

PARAGUASSÚ, L. UnB descarta 212 inscritos no sistema de cotas. Estado de São Paulo, São Paulo, p. A13, 26 maio 2004.

PARRA, F. C. et al. Color and genomic ancestry in Brazilians. Proceedings of the National Academy of Sciences of the United States of America, v. 100, n. 1, p. 177-182, 2003.

PENA, S. D. P.; BORTOLINI, M. C. Pode a genética definir quem deve se beneficiar das cotas universitárias e demais ações afirmativas? Estudos Avançados, v. 18, n. 50, p. 31-50, 2004.

PIRES, F. D. A. Leitores comentam editorial "Tribunal racial” da Folha de São Paulo. Jornal da Ciência, 2004. Disponível em: <http://www. jornaldaciencia.org.br/Detalhe.jsp?id=18266> . Acesso em: 5 maio, 2004.

RABELO, M. L. Por que adotar o sistema de cotas para negros? Correio Braziliense, Brasília, 27 abr. 2004. Gabarito, p. 5.

REZENDE, P. P. O dique da injustiça rompeu: entrevista: José Jorge de Carvalho. Correio Braziliense, Brasília, p. 5, 17 abr. 2004.

RIBEIRO, G. L. Cotas, racismo e antropólogos. Jornal da Ciência, 2004. Disponível em: <http://www. jornaldaciencia.org.br/index2.jsp?id=658>. Acesso em: 5 ago. 2004.

SAI LISTA dos candidatos cotistas. Correio Braziliense, Brasília, p. 26-27, 19 nov. 2004. 
SANTOS, J. R. IPCN e Cacique de Ramos: dois exemplos de movimento negro no Rio de Janeiro. Comunicações ISER, n. 28, p. 5-28, 1988.

SANTOS, R. V. Uma grande fraude. O Globo, Rio de Janeiro, p. 7, 2 abr. 2004a.

SANTOS, R. V. Cotas, UnB e raciologia contemporânea. Correio Braziliense, Brasília, 18 abr. 2004b. Revista D, p. 30.

SANTOS, R. V.; MAIO, M. C. Cotas e racismo no Brasil. Jornal do Brasil, Rio de Janeiro, p. A10, 14 abr. 2004a.

SANTOS, R. V.; MAIO, M. C. O veredicto do tribunal racial da UnB. Correio Braziliense, Brasília, p.17, 12 jun. 2004b.

SANTOS, R. V.; MAIO, M. C. Tribunal racial. O Globo, Rio de Janeiro, p. 7, 6 dez. 2004c.

SANTOS, R. V.; MAIO, M. C. Qual "Retrato do Brasil”?: raça, biologia, identidades e política na era da genômica. Mana: Estudos de Antropologia Social, v. 10, n. 1, p. 61-95, 2004d.

SEABRA, L. Cotas para negros aprovadas. UnB Agência, Brasília, 6 jun. 2003. Disponível em: <http://www.unb.br/acs/> . Acesso em: 21 nov. 2004. SEGATO, R. Você é a favor da cota para negros? Sim. Correio Braziliense, Brasília, p. 30, 18 abr. 2004.

SEGURA-RAMIREZ, H. Revista Estudos Afro-Asiáticos (1978-1997) e relações raciais no Brasil. Dissertação (Mestrado em Antropologia Social)-Departamento de Antropologia Social, Universidade Estadual de Campinas, Campinas, 2000.

SILVA, O. S.; LUZ, L.; HELM, C. M. (Org.). A perícia antropológica em processos judiciais. Florianópolis: Editora da UFSC, 1994.

SOUZA, J. (Org.). Multiculturalismo e racismo: uma comparação Brasil - Estados Unidos. Brasília: Paralelo 15, 1997.

TELLES, E. Racismo à brasileira: uma nova perspectiva sociológica. Rio de Janeiro: Relume-Dumará, 2003.

WEBER, D.; GALLUCCI, M. Marco Aurélio Mello discorda da decisão da instituição de fotografar quem se declara negro. O Estado de São Paulo, São Paulo, 16 abr. 2004. Disponível em: <http://www.estado.com.br>. Acesso em: 25 abr. 2004. 
WEBER, M. Economia e sociedade: fundamentos da sociologia compreensiva: v. 1. Brasília: Editora UnB, 1991.

Recebido em 16/11/2004

Aprovado em 30/11/2004 